DOI No: http://dx.doi.org/10.29228/Joh.47266

Authenticity process is conducted by

Makale Türü: Araştırma makalesi

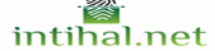

Geliş Tarihi: 31-10-2020

Kabul Tarihi: 15-12-2020

On-line Yayın: 25-02-2021

Article Type: Research article Submitted: $31-10-2020$

Accepted: $15-12-2020$

Published Online: 25-02-2021

Atıf Bilgisi / Reference Information

Kalkan, İ.H. (2021). Public Hygiene and Social Control in Late Ottoman İstanbul. Journal of History School, 50, 1-24.

\title{
PUBLIC HYGIENE AND SOCIAL CONTROL IN LATE OTTOMAN ISTANBUL ${ }^{1}$
}

\section{İbrahim Halil KALKAN ${ }^{2}$}

\begin{abstract}
In the Ottoman Empire, the mid-nineteenth century witnessed the birth of public hygiene as a consistent government strategy, which marks the emergence of an innovative official approach to the exercise of state authority. With the emergence of the public hygiene, the state now became conceived to both survey and shape the urban environment and day-today social and individual lives in a much more pervasive manner and to ensure the health of the population. In addition to tracing the emergence and historical evolution of the late Ottoman public hygiene, this article suggests that it was the historical overlap between the development of a new form of political power and a drastic transformation in medical epistemology that principally paved the way for this policy. I furthermore argue that the Ottoman public hygiene policy intensified significantly from the late nineteenth century due to the particular conjecture of these years, which involved a set of unique developments, both scientific and social-political.
\end{abstract}

Keywords: Public Hygiene, Medicine, Power, Urban Environment

${ }^{1}$ This article is based on my MA Thesis, titled "Medicine and Politics in the Late Ottoman Empire (1876-1909).” Boğaziçi University, 2004.

${ }^{2}$ Assist. Prof., Adana Alparslan Türkeş University of Science and Technology, Faculty of Political Sciences, Department of Political Science and Public Administration, ihkalkan@atu.edu.tr, Orcid: 0000-0001-5135-7841. 


\section{Osmanlı Son Dönemi İstanbul’unda Hıfzısıhha ve Toplumsal Kontrol} $\ddot{O} \mathbf{z}$

On dokuzuncu yüzyıl ortalarından itibaren, Osmanlı İmparatorluğu ve özellikle İstanbul, istikrarlı ve sistemli biçimde halk sağlığı siyasetinin doğuş ve gelişimine sahne olmuştur ve söz konusu siyaset niteliksel olarak yeni bir resmi iktidar anlayışına işaret etmektedir. Hıfzısıhhanın doğuşuyla birlikte halk sağlı̆̆ını koruma çabasıyla devlet kentsel alan ve gündelik kent yaşamını hiç olmadığı kadar derinlemesine şekillendirme ve denetim alma yönünde adımlar atmaya başlamıştır. Bu çalışmada halk sağlığı siyasetinin ortaya çıkışının yeni bir iktidar biçiminin gelişimiyle tıbbı epistemolojide yapısal dönüşümün zamansal örtüşmesiyle açıklanılabilineceği önerilmektedir. Ayrıca, dönemin resmî belgelerine dayanılarak, on dokuzuncu yüzyıl sonlarından itibaren halk sağlığı siyasetinin yoğunluğunda hızlı bir artış olduğu gösterilmekle birlikte söz konusu artışın gerek bilimsel gerek toplumsal-politik bir dizi özgün gelişmeyi içeren bu yılların tarihsel bağlamının sonucu olduğu açıklanmaktadır.

Anahtar Kelimeler: Hıfzısıhha, Tıp, İktidar, Kentsel Çevre

\section{Introduction}

The late Ottoman Empire, the late nineteenth century, particularly the 1890s, witnessed enormous efforts by the state to reorganize both the urban space and social life in İstanbul through vigorous measures of public hygiene. As regards both form and intensity, these measures were arguably unprecedented in Ottoman history. Over the course of these years, in addition to establishing a group of institutions to engage the matters of public hygiene, the ruling authorities issued a set of comprehensive policies formulated with the declared purpose to keep the city under scrutiny to prevent the emergence and spread of particularly contagious diseases. These policies involved the regular hygiene inspections of public places and potentially overcrowded residences, such as mosques, hospitals, cemeteries, factories and workshops, coffeehouses, hostels, inns and bachelor chambers. In addition to the regulation of the physical conditions and furthermore regular and obligatory disinfections of these places, these inspections routinely produced detailed reports on what had been and what should further be done to resolve such significant problems as the dirtiness of water, lack of proper sewage disposal, insufficient ventilation, filth and odor and overcrowding particularly in poor dwellings. Furthermore, the committees formed to provide sanitation to the city embarked on compulsory vaccination campaigns as well as the regular collection of statistics on birth and death.

This article explains the emergence and evolution of the late Ottoman public health policy over the course of the nineteenth and early twentieth century. 
It was the mid-nineteenth century when public hygiene emerged as a consistent and systematic official policy in the Ottoman Empire and, to explain the birth of public hygiene, I suggest that the reason lies primarily in the overlap between a drastic transformation in medical epistemology and the development of a new form of political power. Then, I explain comprehensively how the public hygiene policy intensified toward the end of the nineteenth century. By relying mostly on a set of primary archival records, I demonstrate through which innovative ways and how deeply the state now intervened in the daily lives of the city's inhabitants, with the city being imagined by the ruling authorities as a body. By also discovering the mindset of the ruling elite regarding the question of public hygiene, through the discourse that they employed to suggest what should be done to transform the city to better the conditions, I finally discuss why the Ottoman public hygiene policy intensified specifically during the 1890s.

\section{The Transformation of Medicine and Emergence of Public Health in Ottoman Empire}

Over the course of the nineteenth century, particularly from the 1830s onward, the conceptions of both medicine and the body drastically changed in Ottoman Empire. This transformation in the domain of medicine was marked most significantly by the birth of pathological anatomy, which brought about a significant change also in the understanding of the disease. Traditionally in the Ottoman Empire, according to the classical medical epistemology, every single body had been conceived to have its own and unique character. Therefore, in terms of both medical examination and treatment, the body had been regarded individually, with the disease being related to a body's unique character and therefore also individually identified and treated (Shefer-Mossensohn, 2009, p. 21-29).

Toward the end of the 1830 s, it was, in the first place, the foundation in 1839 of a new medical school, the first modern medical college of Ottoman Empire, Mekteb-i Tibbiye-i Şahane that marked and embodied the categorical transformation in the understanding of the disease and body. Alongside its institutional organization and curricula, what particularly made the school a breakthrough in the history of Ottoman medicine is the performance of anatomical dissections for the purpose of medical education (Demirhan \& Kahya, 1997, p.114-116). The significance of anatomical dissection lies primarily in that it indicated a categorical transformation in the conception of disease through the birth of pathological anatomy. With the pathological anatomy, then, diseases were perceived to originate in the organs of the body and emerge as a result of 
microbiological processes. In addition to finding the exact location of a disease inside the body, dissections have also taken on the main purpose of tracing the chain of causes and effects embedded in these processes that produce a disease in the body (Foucault, 1973, p.122-148). Furthermore, the new medical perspective has conceived the process through which the disease emerges as scientific and therefore universal, in other words, always the same regardless of who the person inflicted with the disease is. Thus, it was the disease and its nature that now became the focus of medical attention, rather than the individual body, with the causes of the disease being universal and the body falling into the status of simply the carrier of a disease. By depriving the body of its uniqueness and therefore meaning, the new medical understanding made it possible to conceptually anonymize the body (Foucault, 2000, p.134-138).

Once the body became conceptualized simply as a biological entity with essentially the same nature in every single person, and the disease to occur by following always the same causal process in every single case, the medical perspective has focused on the disease not only at the individual level but also across the society. The understanding of the disease as in the first place a social phenomenon historically paved the way for the active state intervention into social life to prevent the emergence and spread of particularly contagious diseases, a policy whose beginning can be traced to the early 1840s and which gradually evolved further into also the sanitation of the urban spaces and encouraging the health of the population.

The mid-nineteenth century witnessed state intervention into the day-today social life in a way that extends beyond the domain of public health. These years indeed witnessed the emergence of a new form of political power which envisaged an increasingly centralized and hierarchically organized bureaucracy functioning through well-delineated and predictable procedures, increasing central political control over the provinces and new mechanisms of government whereby to increase social control over the population. Notwithstanding that this development stretches back to at least the late eighteenth century, the consistent set of reforms known as the Tanzimat (reorganization) which started from the early 1840s and whose guiding principles the Gülhane (Rose Chamber) Edict (1839) laid out constituted a breakthrough in this development.

The Gülhane Edict represented a drastic transformation in the ideology of the Ottoman state. Putting the law above all personal authority, including that of the sultan, and by concomitantly declaring that everybody was bound by the law in his actions, the edict envisaged that absolutism be replaced by the rule of law as the core principle for the exercise of political power. Furthermore, and 
concomitantly, the edict brought about the principle of individual rights and equality between individuals before the law and vis-à-vis the state. Thus, in contrast to the former official Ottoman understanding of the power and law where the law was conceptualized as the reflection of the sovereign's will and the power foremost as a personal relationship between the ruler and the governed, the edict was a significant step to abstract the law into universal norms based principally on the individual rights, through which, at the same time, it also envisaged an impersonalized form of power (Kalkan, 2015).

One can suggestively note that it was not a coincidence that it was during the same years when the body was conceived as possessing always and essentially the same biological characteristics and all the persons as having equally the same legal and political rights and social and psychological dispositions. These two developments contributed to and reflected the abstraction of the population into the society, with the society being conceived of as an abstract entity to be shaped and controlled by the political power (Foucault, 2000). Accordingly, as has already been suggested, the political control of the society developed over the course of the nineteenth century in a way that included but went beyond the public health policy. From the early nineteenth century onward, among the many ways through which this development expressed itself are compulsory conscription following the emergence of the standing army, the organization of a modern police force, independent from the army and assigned to detect crime across the society, conduct criminal investigations and establish public security and order, population censuses recording comprehensive information about all the individuals and institutionalized and systematic spying on the society to bring together the knowledge of particularly political activities and opinions (Shaw, 2002, p.1-171; Kırl1, 2000, p.245-286).

As an extension of the same underlying development toward rendering the social life well-ordered, knowable and shapeable, according to which the government policies evolved over the course of the nineteenth century, the midnineteenth century also witnessed the emergence of a new conception of the city in the Ottoman Empire. The urban planning projects that then accordingly emerged took on the purpose of transforming the city into a well-ordered space where both social and individual lives were to play out in predictable ways. The late Ottoman politicians who carried out the Tanzimat reforms also envisaged producing a well-connected and integrated city through on the one hand geometrically laid out streets lying symmetrically to each other and connected to newly opened arteries and squares and on the other building up a comprehensive public transportation system. Accordingly, over the course of the nineteenth century and with the use of especially European experts, engineers and architects, 
the government coordinated the development of grand-scale urban planning projects and set out to engage in institutionalization for urban reform, which started most significantly with the Intizam-l Şehir Komisyonu (the Committee on the Order of the City) (1855) and followed by the others with increasingly sophisticated assignments.

The urban reform in late Ottoman Empire took shape for a set of purposes. A well-ordered city, both physically and socially, was expected to contribute to public security and order by making the city observable, thus facilitating to detect what is happening inside the city. In addition to much more efficiently policing the urban environment, the reforms also aimed to produce an image to the outside world of a beautifully ordered and pristine city. Finally, and perhaps most significantly, the Ottoman ruling authorities projected the urban reform for the sake of public health, as filth and dilapidation coupled with overcrowded public spaces and residences meant the growth of diseases across the society (Çelik, 1993, p.31-48). As will be explained below, the development of bacteriology then increased the significance of the spaces and social interaction concerning the emergence of diseases. For therefore the sanitation of the city, urban architecture and planning was to play a critical role. Particularly for providing ventilation, the organization of streets and squares, construction material and building and apartment designs became urgent issues for the public authorities.

\section{The Ottoman Public Health Policy until the Late Nineteenth Century}

With the nineteenth century in Ottoman Empire, the state assumed direct responsibility for medical services, which had formerly been principally a matter of charity (Zorlu, 2002; İnalc1k, 1994, p.140-45; Yilmaz \& Y1lmaz, 2006). Particularly, the mid-1840s onwards witnessed the beginning of a consistent policy to monitor and shape social life for the ends of public hygiene, which involved the opening of special institutions, emergence of new concepts and educational efforts. The first modern medical college of the Ottoman Empire, Mekteb-i Tibbiye-i Şahane, whose organization followed the new medical epistemology, from the beginning included in its curricula the courses on public health in addition to those of clinical medicine. From the mid-1840s, the school's curricula furthermore included the courses on the "medical police" (tıbb-i zabita). As suggested then by the chief director of the school, the "medical police" was a new and modern scientific domain whose purpose was to explore and deal with the dynamics that damage the health of the population and prevent population increase (Kahya, 1997, p.10-12). 
At the time when the Mekteb-i Tibbiye was established, the government organized the Committee for the Health Protection (Meclis-i Tahaffuz) whose declared purpose went beyond taking quarantine measures and which in this respect has been counted as the first Ottoman institution to engage in public health (Demirhan and Kahya, 1997, p.123-124). The following decades witnessed the organization of several more institutions to engage in matters of public health, with increasingly more sophisticated functions. Most significant among these are the Meclis-i Umur-u Tibbiye-i Mülkiye (the Committee on Civil Medical Affairs), established in 1857 within the Mekteb-i Tibbiye to coordinate public health research and services (Özen, 1981, p.368) and the Cemiyet-i Tibbiye-i Mülkiye (Society of Civil Medicine), organized in 1869, that constituted the origins of the later Ottoman Ministry of Health. The Cemiyet- $i$ Tibbiye's functions included appointing medical personnel throughout the empire, the supervision and inspection of official health services, taking precautionary measures against the emergence and spread of epidemics and other contagious diseases and supervising forensic medical investigations into the causes of deaths (Ylldırım, 1985, p.1320-1322).

Mekteb-i Tibbiye-i Şahane which the Ottoman reformers founded in 1839 as the empire's first modern school of medicine was a military college. Nevertheless, the school's domain of activities extended much beyond the army to include the whole society. In addition to training physicians to serve throughout the country, the college produced public health policies and coordinated all the medical services across the population. Nevertheless, to answer the declared urgent need for training physicians educated according to the new and scientific principles and methods of medicine, the government established the first civil medical college of the empire in 1867, Mekteb-i Tibbiye-i Mülkiye (Civil Medical College) (Karatay, 1971, p.10-12; Unat \& Samast1, 1971, p.112-115). Later at the turn of the twentieth century, these two medical colleges were united under the name of Darülfünun (house of sciences) Medical Faculty (Demirhan \& Kahya, 1997, p.116-118). Over the course of the nineteenth century, the opening of medical schools to train "well-educated" physicians coincided with the systematic policy to regulate and standardize the medical profession, with the main purpose being that only the graduates of the modern medical colleges and other officially authorized specialists could perform medical services (Ylldırım, 1985, p.1320-1322).

Another significant development as regards the institutionalization of public health in nineteenth century Ottoman Empire was the sudden increase in the number of government hospitals both military and civilian. This policy again involved a categorical change in the Ottoman medical system: while hospitals 
had formerly been established and funded by the sultan, members of the dynastic family or high-ranking bureaucrats principally for charitable purposes before the nineteenth century (Yilmaz \& Y1lmaz), it was now the government that both founded and administered the hospitals as a systematic official policy and according to well-delineated procedures. In addition to providing people with free medical care, the most significant purpose of the hospitals became to monitor the health of the population and prevent the spread of contagious diseases (Şehsuvaroğlu, 1953, p.62-66; Demirhan \& Kahya, 1997, p.118-122).

A significant dimension of the nineteenth century Ottoman public health policy was the development of vaccination across both the army and population in accordance with the introduction of bacteriology into the empire. Vaccination and inoculation became institutionalized from the early 1870s and evolved over the following decades, together with the scientific development of bacteriology where the use of the Pasteur method by the late 1880s constituted a breakthrough (Yıldırım, 1985, p.1326-1338).

The nineteenth century Ottoman public health policy focused primarily on fighting contagious diseases including rabies and hydrophobia, cholera, typhoid, leprosy, tuberculosis, dysentery and syphilis (Y1ldırım, 1985, p.1326-1334). With regard to reflecting the government policy to control the social life for the sake of public hygiene, particularly notable were the measures taken against syphilis. Because, being a venereal disease, the principal cause of the spread of syphilis is extramarital sexual intercourse, the state authorities set out to deal with the question of prostitution. However, instead of completely banning prostitution, they followed a consistent policy to regulate this practice. Accordingly, in the mid-nineteenth century, officially authorized brothels emerged for the first time in Pera and Galata districts of İstanbul, with the women working in these places being registered. Eventually over the following decades, this policy became more sophisticated, with regular medical inspections of the brothels and routine medical examinations on the women. The women who were found infected with venereal diseases, particularly syphilis, were compulsively interned in the Women's Hospital (Altıncı Daire-yi Belediye Nisa Hastanesi) established in 1879 (Yildirım, Tanimat'tan, p.1326-1334). Over the course of the late nineteenth century, the government developed plans to implement such measures which started in İstanbul also in the other parts of the empire, particularly the significant port cities and Black Sea Region where the rate of syphilis was the highest (BOA (1891), A. MKT. MHM. 502/23), (BOA (1899), YA. RES. 99/32). 


\section{Public Hygiene and Social Control in Late Ottoman İstanbul}

\section{Public Health in the Turn-of-the-Twentieth Century İstanbul}

As suggested by both the surveys of Ottoman medical history and more significantly the numerous records housed in the Prime Ministry Archives, İstanbul, the 1890 s witnessed that the Ottoman public health policy suddenly intensified with regard to both institutionalization and official efforts to pervade deeper into daily social life. Regarding the institutionalization which involved both the emergence of new organizations and increasingly more comprehensive functions of official bodies concerned with public hygiene, arguably the most significant development was the organization of a standing committee, the Committee of Public Hygiene (Hifzislhhat-l Umumiye Komisyonu). It was established in 1894 and as a part of the İstanbul Municipality. While the Committee of Public Hygiene was responsible for coordinating the public health policy over the whole city of İstanbul, the government simultaneously established the boards of health attached to the committee, which were to deal with public health matters over the municipal administrative districts. Their activities marked an intrusion into the daily lives of the city's inhabitants on an unprecedented scale.

The committee was designated to regularly conduct statistics of birth and death and accordingly produce monthly tables. It was furthermore to investigate the cause of every death within the city and carry out official inquiries into the rates of birth and death, in addition to exploring the dynamics that influence the population growth. Within the areas of their responsibility, the boards of health were assigned to routinely submit reports on the reasons behind the emergence of contagious diseases and find out the measures to be undertaken to prevent their spread. They were also to carry out the cleansing and disinfection particularly of potentially overcrowded places including residences such as inns, rented-out rooms in commercial buildings and bachelor chambers. Furthermore, they were responsible for compulsory post-mortem examinations into all the deaths. After ensuring that government physicians conducted the post-mortem examinations properly, the boards issued burial licenses. They also were obliged to regularly report all the deaths and their causes (BOA (1894), YA. RES 72/1).

The boards were to carry out weekly inspections tours on which they should prepare reports. In addition to the disinfections conducted, these reports should include the efforts spent to deal with crowding in public spaces and residences. They should also involve information about vaccination activities and the results of the regular hygiene inspections on commercial food and drinks. Regarding a person found infected with a contagious disease, the boards should trace the information all the way back to where he came from, since when he had 
been living in his current residence, when exactly the disease occurred and whom he contacted until then. They in addition were to determine the extent to which the disease spread throughout the city and the number, if any, of people who died of it (BOA (1894), YA. RES. 72/1).

From the 1890s the government established disinfection stations attached to municipalities, which were to conduct the cleansing and disinfection of urban spaces. It simultaneously appointed special officials trained to manage scientific cleansing. In addition to fighting already existing contagious diseases by disinfecting the spaces and material that constituted their seedbeds, these officials were also responsible to sterilize all the spaces throughout the city that they located as the potential sources of diseases (Ergin, 1995, p.3140-3142). The special regulation on disinfection stations also stipulated that within the neighborhoods, the religious leader (imam), administrative head (mukhtar), guard (bekçi) and müstecirs (those who routinely rent out apartments or rooms to particularly the urban poor and particularly still the single males) all were kept responsible to permanently keep surveillance over public spaces and rented-out dwellings to ensure that a contagious disease was urgently reported. The regulation furthermore stipulated that the rented-out dwellings should be cleansed every time they changed hands, and other places once a month, which included public baths, brothels, coffee houses and public transportation and commercial shops and workshops. The regulation involved a special emphasis that the places where bachelors and strangers (gureba) lived should not be crowded, as these places were already potential sources of disease due to their physical conditions, e.g. lacking enough ventilation and light (Ergin, 1995, p.3219-3235).

The archival records allow us to see significantly the activities involved by the inspection tours conducted by the Boards of Health. During these routine and periodical inspections throughout the city, as envisaged by the regulations, one witnesses most notably the cleansing and disinfection of insalubrious spaces. In addition to the special attention paid then to the poor residences, the main targets of these sanitation campaigns were such commercial spaces as shops, workshops, pubs, taverns, coffeehouses, restaurants and public baths. Alongside cleansing and disinfection, the most common activities were lime and whitewashing, evacuation to prevent overcrowding, covering sewers and drains in order particularly to block odors and installing toilets with flushes. To more concretely see how the sanitation policy was practiced on the ground, I proceed below with examples of the measures either envisaged or implemented during these inspection tours. 
During the inspection conducted through Kemeraltı and Yüksekkaldırım Streets around Galata, the shop of one Kosti, a chicken farmer, was found to be extremely filthy and spreading fetid odors. In addition to most of the chickens being rotten, the feathers of slaughtered chickens smeared with blood were exposed to the open air, thus posing risk for the environment. The shop was both disinfected and whitewashed (BOA (1901), Y.PRK. ŞH 11/116). Over the same days, around Kasımpaşa, the medical inspectors cleansed two hans and installed their toilets with flushes. Furthermore, they required that all the garments in a clothing store be ironed. They had the shop of the dairyman Yorgi repaired and cleansed its back garden which had been diffusing fetid odors. They in addition located a number of rag houses built of tinplate, lying beside a brook and dilapidated. After evacuating the people living in these rag houses, the inspectors demolished them and cleansed the area where they had been located. Furthermore, the inspectors found a number of stables dangerous for health and cleansed and closed them down, covered a vacant lot used by a coal dealer with wooden bars and ordered one Mehmed, the owner of a modest restaurant, to have the pots in his shop tinned. Alongside cleansing a laundry and some bakeries, the inspectors located that a confectioner used insanitary dyes in his shop. In addition to disposing of these dyes, they also located and disposed of the candles made of them and sold around. A police sentry shed nearby a brook was found to have been diffusing a fetid smell. The police were removed to another place with proper conditions for health that the medical inspectors located. The medical inspectors found during this inspection tour three people ill of ordinary diseases (ilel-i âriye), who would be treated "at the mercy of the sultan," and did not locate anyone infected with a contagious disease. Previously in the vicinity, a number of people sick of an infectious disease, as well as those found to have contacted them, had been quarantined and everything had been normal with them (BOA (1901), Y.PRK. ŞH 11/116).

About ten days later, during another daily public hygiene campaign conducted through Balıkpazarı, Hocapaşa and Sirkeci (BOA (1901), Y.PRK. ŞH. 11/78), the medical inspectors had the toilets of a commercial complex installed with flushes and the building repaired. In another one, they removed the sheep fleece left to dry in the courtyard. They covered the gridiron of a street's main sewer by a lid and somewhere else covered the watercourse of a sewer belonging to a tannery. Furthermore, in addition to dealing with the muddy water produced by water flowing from fountains, they had the pavement of a leather dyeing house repaired. Also, finding the house of a scribe overcrowded, they required that the number of people living there be reduced (BOA (1901), Y.PRK. ŞH. 11/78). 
One of these inspection campaigns (BOA (1901), Y. PRK. ŞH 11/91), which took place over the following month, involved the repair of a tannery's pavement and cleansing of hans, groceries, bakeries, horsecloth shops, coffeehouses, restaurants, stables and sweet shops. Furthermore, in addition to certain groceries, butchers, restaurants, coffeehouses and stables being limed and whitewashed, the medical inspectors sterilized the lavatories of certain pubs, groceries and yoghurt shops. They also sterilized several public baths, evacuated and shut down a number of dairyman kiosks and demolished the isolated mounts of rocks (BOA (1901), Y. PRK. ŞH 11/91).

An inspection campaign from the same days and conducted through the Samatya region focused particularly on the hygiene of toilets and condition of sewers. The inspectors disinfected the toilets of various commercial spaces including coffeehouses, pubs, nightclubs, restaurants, groceries and butcheries and whitewashed a part of them with lime. Furthermore, in three separate bakeries, the inspectors found the toilets and sewers too close to the wells and relocated them to a reasonable distance (BOA (1901), Y.PRK. ŞH 11/88).

During these inspections, the medical specialists focused particularly on the dwellings where the urban poor, particularly single immigrant workers resided. This type of place included rented out rooms in apartments and hans, bachelor chambers and also workshops and coffeehouses. Commonly, the inspectors conducted the cleansing and disinfection of these places by paying special attention to their toilets. In addition to calling attention to the filth and fetid odors emanating from these dwellings, the medical inspectors often emphasized overcrowding within them. Indeed, their reports included warnings that the cleansings would not be a solution to improve the conditions of these places unless they were significantly vacated or it was dangerous that such large number of people squeezed in such narrow a space. To put more concretely, in one of these reports, with regard to an apartment building located through one of the daily campaigns, the inspectors stated that it was filthy and dilapidated to the extent of being uninhabitable. Even the cleansing proved inadequate to make one of the apartments suitable for residence. To ameliorate the conditions, they cleansed and whitewashed the apartments, especially their toilets. Nevertheless, the apartments were too crowded for these measures to achieve hygienic standards. The inspectors further and emphatically noted that they located many similar cases through the campaign (BOA (1901), Y.PRK. ŞH. 11/116). Indeed, over the course of the inspection tours conducted through different parts of the city, one significant and common activity was the cleansing of apartments and bachelor chambers, which, emphasize the reports, were done according to 
"scientific methods" (BOA (1904, Y.MT. 262/180), (BOA (1901), Y.PRK.ŞH. 11/88).

As these inspection reports also suggest, increasingly over the course of the late nineteenth and early twentieth centuries, public authorities viewed the urban poor and their residences as the potential sources of contagious diseases and therefore constituting serious risks to the whole city. Consequently, in addition to spending efforts to ameliorate the conditions of poor residences, especially through cleansing and sterilization, the official authorities were also seriously concerned about keeping particularly the immigrant poor distant from the central and significant locations within the city.

This incident is illustrated vocally by an incident from the early 1890 s. Accordingly, the municipality set out to deal with a group of poor Jewish people living in shacks packed together in Ortaköy. Their dwellings were in miserable conditions, most notably, filthy, fetid and overcrowded. As it was dangerous and intolerable that they should keep living there, the municipality decided to remove them, with their dwellings being demolished. The municipal authorities were nevertheless confronted with the question of where to remove them. They finally located a vacant plot in the vicinity, where they planned to build a group of small houses with proper hygiene, with all the costs being provided by the Jewish community. They would thereby overcome the harm and risk emanating from these people's living conditions. When the municipality requested the approval of this project, the palace refused with the remark that in the vicinity where the houses were to be constructed, there were the administrative offices of the upper bureaucracy as well as the imperial family residences (BOA (1893), A.MKT.MHM., 591/3).

The Committee of Public Hygiene and the Boards of Health were additionally responsible to conduct vaccination campaigns throughout the city. In accordance with the increasing efforts for public hygiene, over the course of the late nineteenth and early twentieth century, vaccination activities also intensified in İstanbul. The late 1880s and 1890s witnessed the introduction of the Pasteur Method in Ottoman Empire, based on which the inoculations were then performed. Over the course of the same years, several new institutions emerged for the sake of vaccination. Alongside opening vaccine factories, the government first opened the Institute of Rabies (1887), which also dealt with all matters of bacteriology, and then followed with the Institute of Smallpox Vaccination that also functioned as a vaccination school. Finally, when cholera reached epidemic proportions in İstanbul, Sultan Abdülhamid II requested the advice of Pasteur under whose guidance the Institute of Bacteriology (1893) was established. Again 
with Pasteur's advice, the sultan appointed a French doctor, Maurice Nicolle, as the Institute's director. In addition to conducting scientific research and producing vaccines and serums, the institute was also responsible to examine the healthiness of the city water. Furthermore, alongside being the director of this institute, Dr. Nicolle also offered proposals about how to deal with the matters of public hygiene, including the one on pipes across the city (Yildırım, 1985, p.1336; BOA, 1894, Y. PRK. AZJ, 28/45).

The opening of this institute was followed with the institution of bacteriology laboratories in the hospitals over the city. Following the institutional and scientific evolution of bacteriology, throughout İstanbul and under municipal coordination, routine vaccination campaigns were conducted, through which hundreds of thousands of people, particularly children, were inoculated (Yildirım, 1985, p.1335; Kranzler, 1991, p.152). Because the government held the inoculation of all the children in the city compulsory, in addition to the registers of the children vaccinated, the municipality spent intense efforts to ensure that birth records were regularly kept and reported (BOA (1909), DH. EUM. THR., $15 / 31)$.

The ruling elite's intense concern with public hygiene in İstanbul over the course of the late nineteenth and early twentieth century, as well as the problems that they viewed as particularly significant, can also be traced from the public discourse they employed during these years. One significant source to trace this public discourse is a yearbook called Nevsal-i Afiyet, edited and published by Besim Ömer Paşa, a scholar of medicine as well as a leading bureaucrat and reformer who significantly shaped the public health policies (Dinç, 1989, p.91). Among the articles published through, two are particularly telling. They comprehensively articulated the mindset of the elite concerning public hygiene, particularly on the question of why it was an urgent issue to which the government should pay significant attention. They both often took on a didactic tone while laying out the urgent problems as well as proposing how best to resolve them. It deserves particular emphasis that there is a significant overlap between, on the one hand, the public health policies followed by the government, and on the other, the remarks and proposals made by these articles.

Taking more of a conceptual tone, the first one (Akalın, ed., 1906) titled, Bir Şehrin Hifzısihhat (the Hygiene of a City) deployed the metaphor of the body and the city, by conceptualizing the city as a living organism with its own life and therefore being subject to health and disease and likening streets to veins, air and light to blood and sewers to intestines. Because, similar to the body, all the constituents, even the smallest ones, had a significant effect on the whole, public 
authorities should closely survey all the processes taking place within the city. Among them, the article emphasized particularly the circulation of germs and particularly still the dust through which germs travel within the city. Calling it "the wings of germs," helping germs to reach everywhere, including domestic spaces, the article suggested the dust as the most significant cause for the spread of diseases. Particularly to overcome the dust, the city should be planned in a way to allow the free circulation of air. Likewise, for creating a healthy urban environment, the light should easily diffuse the streets and more significantly inside houses, for which wide streets were essential. The other measures considered vital for public health within the city were keeping streets clean of refuse particularly by routinely sweeping them, the routine inspections of city water, building a sophisticated and scientifically designed sewer system and increasing the amount of grass and groves for the water to be absorbed by the ground.

As suggested by its title, Inşâ ve Hıfzısıhhat-ı Mesâkîn (the Construction and Hygiene of Houses), the second article (Akalın) ed., 1904) focuses on the question of housing hygiene by calling attention to the poor conditions particularly of the houses of the poor in İstanbul. They had too small and narrow rooms with windows whose size was disproportional to that of the house mostly due to the construction materials. These houses were easily penetrated by damp, with their floors and planks being widely set apart and the walls ruined. These all were combined with the disorderly channeling of water and inappropriate sewage disposal.

By resorting often to the notion of civilization with regard to urban planning and organization of city life, the article emphasizes that residential areas should be distant enough from forests and sea to prevent the damp from rising, in addition to being also distant from cemeteries, workshops and factories. Particularly the workshops, and particularly still those producing rag and leather, candle and soap, which quickly spread around filth, dust, poisonous gases and fetid odors should be kept distant from residential areas. Alongside recommending the use of concrete and lime in the construction of houses, the article suggested that for choosing the ground for building houses vital significance should be attached to resistance to humidity, as the humidity was arguably the most significant reason for the emergence of especially contagious diseases.

Similar to the other one, this article likewise emphasizes that buildings should be widely set apart from each other for the air and light to diffuse sufficiently into their interiors. It nonetheless also stated that since about forty 
years and thanks to the municipal laws, one could observe a considerable decrease in the number of streets with houses built closely together. Similar to the hygiene inspections conducted throughout the city, one can also here trace a particular emphasis on toilets, those of both public spaces and houses. The article lays out in detail the rules for toilet hygiene, most significantly, the requirement of installing toilets with flushes to prevent the air rising from the sewage from mixing with the air of the house.

Again, reminding one significantly of hygiene inspection reports explained above, excessively crowded housing outstands as the most significant issue addressed in the article. Seeing an obvious and proportional relationship between crowding and the risk for contagious diseases, the article suggests that to prevent the rise of contagious diseases all the measures such as those concerning the city water and sewers proved insufficient, as the question of overcrowded houses remained unresolved. The overcrowded housing coupled with the filth and the other poor urban and architectural conditions fatally disturbed the public health policy.

Indeed, the article explicitly classified overcrowded housing as the Mesâkîn -i Fukara or Fukara Meskenleri (dwellings of the poor) where, it stated, these conditions combined were commonly observed and which therefore were the source of contagious diseases. It further and openly defined them as the places where the poor and destitute (fakir ve bikes) resided, including bachelor chambers, shanties, the rooms within apartments or commercial complexes rented out to mostly immigrant, male and single laborers. A typical one was about twenty squares meter where ten or more people were packed together in hard and extremely unhealthy conditions, thus lacking a sufficient amount of oxygen. The neighborhoods where they were located were dark because of the streets too narrow to allow the penetration of light, with the dwellings being close to each other to the extent that one could easily cross over from one to the other through the windows. The streets also were clogged with filthy water, which accumulated on the streets and was absorbed by the ground, penetrated the wells, buildings' foundations and their ground floors. The buildings were filthy, damp and with dirty walls. As a result of all these conditions, these neighborhoods were full of and spread around fetid odors.

The article found it significant that the municipal regulations envisaged the regular cleansing and disinfection of the poor dwellings, which nevertheless could bring about only temporary improvement. As a long term and much more efficient measure, the article proposed to provide the poor with housing built according to the standards of hygiene, through low prices, with the payment being 
very long-term and in small pieces. It finally suggests that such a policy would also significantly contribute to reforming the morality of the poor, which was spoiled by poverty, overcrowding and filthy living conditions.

Why did the Ottoman public health policy in İstanbul intensify over the course of the late nineteenth and early twentieth century? One significant development that spurred the concerns of the authorities was the rise of cholera epidemics within the city over the course of the 1890s (BOA (1894), YA. RES $72 / 1$ ). Nonetheless, although the contagious diseases, cholera in particular, had taken on epidemic proportions previously in the early and mid-nineteenth century (Kranzler, 1991, 20-24, p.128,134), this then did not produce the same response from the public authorities. The development of the bacteriology and germ theory of disease in the last quarter of the nineteenth century played a significant role to make these years unique. If the diseases spread through the germs easily travelling throughout the city, it then appears urgent to regulate urban life, including both the public and private spaces. Thus, in accordance with the development of bacteriology, the disease became much more social, and therefore political (Rosen, 1993, p.270-320; Porter, 1999, p.139-144).

As suggested, and often explicitly stated, by on the one hand the hygiene inspection reports and on the other the discourse of the ruling elite, it was the overcrowding that particularly alarmed the authorities with respect to diseases and hygiene. Overcrowding became particularly immense in İstanbul toward the end of the nineteenth century due to the huge and sudden population increase. These years witnessed mass immigration from outside the empire into İstanbul, as a result particularly of the 1877-78 Ottoman-Russian War. This was coupled with immigration from within the empire due particularly to the development of service sector and industries in İstanbul. As partly an extension of the population increase, and being a significant cause of overcrowding, the poverty and urban poor emerged as an all too immense and significant problem to the government at the turn of the twentieth century (Özbek, 2002, p.75-80).

Being seen as the seedbeds of the diseases spreading throughout the city, the overcrowded and unhygienic housing was almost identified with the urban poor in the eyes of the public authorities. Consequently, and indeed, the Ottoman public health policy from the late nineteenth century almost essentially meant dealing with the problem of poverty and urban poor. Alongside public order and security, public hygiene was one of the two main dimensions through which the government viewed the urban poor as a significant problem. Likewise, in the same years when the dwellings of the poor increasingly became the target of the official public health policy, the government set out to control to lives of the urban 
poor also and especially through the vagrancy laws (Özbek, 2002, p.78-202). Openly defining the vagrant as the people living in the places classified as the poor dwellings such as and particularly the bachelor chambers, the law authorized the police to register where these people live and inspect whether they regularly spent nights there (Ergut, 2003, p.11). To remember, as an extension of the public health policy, in addition to the disinfection of the poor dwellings being compulsory, the medical inspectors were granted the authority to limit the number of people living in these places and require that they were cleansed scientifically every time they changed hands.

Finally, the significant acceleration in the development of the modern mechanisms of government in the last quarter of the nineteenth century contributed critically to the intensification of the public hygiene policy. These years witnessed the further institutionalization of the bureaucracy through much more sophisticated laws, regulations and procedures, which brought about a more efficient hierarchical organization and smooth administrative functioning (Shaw, 2002, p.172-272).

\section{CONCLUSION}

From the mid-nineteenth century in the Ottoman Empire, the epistemology of medicine transformed to drastically change the meanings of both the body and the disease. Both the nature of the body and the processes through which diseases occur were now increasingly conceived as universal and therefore predictable. Over the course of the same years, this new medical understanding was coupled with the gradual emergence of a new form of political power, whereby on the one hand the Ottoman subjects became conceived of officially as individuals, equal to each other before the law and with respect to the rights and on the other these individuals were together abstracted to the society conceived of officially as a single and whole entity to be shaped and controlled by the state.

Around the mid-nineteenth century, the official Ottoman public health policy that was pursued consistently and systematically was born arguably at the intersection of these two developments. From then onwards, the state authorities spent increasing efforts to monitor and reshape the urban life to ensure that the standards of hygiene were met and to prevent the emergence of epidemics and other contagious diseases. These efforts involved a variety of mostly novel practices that included tracing and recording all the births and deaths, planning the city in a way to provide the free circulation of air and light, proper channeling of water and healthy sewage disposal, the close inspection of drinking water and 
food, training medical specialists, opening state hospitals that offered free medical care, conducting vaccination campaigns and the emergence of officially authorized and inspected brothels.

Toward the end of the nineteenth century, the Ottoman public health policy intensified dramatically, with its character also significantly changing. Over the course of these years, with the help of novel institutions and more sophisticated regulations, the city became much more closely scrutinized. Then, particularly the municipal authorities set out to more drastically shape the urban environment and life, engaging innovatively with such matters as the material of which the buildings were constructed, how to improve the condition of toilets inside buildings and the number of people living in residences. Most significant and innovative among the measures they employed was the compulsory cleansing and disinfections of the neighborhoods and houses of the urban poor, which indicates an unprecedentedly deeper intrusion into the daily and domestic life within the city. Indeed, the official public health discourse in these years envisaged that all the components of the city and everything happening has a critical impact on the well-being of its inhabitants and should be closely observed and controlled. Significantly, the medical specialists and bureaucrats then also expressly metaphorized the city as a body.

It was primarily the overlap between the rise of the cholera epidemic in İstanbul and the development of bacteriology in the Ottoman Empire that helped this breakthrough in public health policy to occur, with the bacteriology prompting the authorities to imagine the city as an integral body particularly to prevent the spread of contagious diseases. Furthermore, the dramatic population increase in İstanbul suddenly intensified the entwined problems of overcrowding and poverty, which were closely associated with public health. Over these years, the poor emerged as an official category of identification for the sake of public health, alongside public security.

The idea of the social body emerged and significantly paved the way for the public hygiene in the mid-nineteenth century Ottoman Empire. It appears that the particular historical conjuncture from the 1890s onwards, and with the help of the modern mechanisms of government that gradually evolved over the course of the nineteenth century, improved this idea in the minds of the late Ottoman politicians to make possible the culmination of the Ottoman public health policy. 
İbrahim Halil KALKAN

\section{REFERENCES}

\section{Primary Sources}

The Prime Ministry Ottoman Archive, İstanbul (Başbakanlık Osmanlı Arşivi), BOA

A.MKT. MHM (Sadaret Mektubi Kalemi Mühimme Odas1

DH.EUM. THR (Dahiliye Nezareti Emniyet-i Umumiye Müdüriyeti Tahrirat Kalemi

YA. RES (Y1ldız Sadaret Resmi Maruzat)

YMT (Yıldız Mütenevvi Maruzat)

Y.PRK.AZJ. (Yıldız Perakende Evrakı, Arzuhal ve Jurnaller)

Y. PRK. ŞH. (Yıldız Perakende Evrakı, Şehremaneti Maruzatı)

\section{Books \& Articles}

Akalın, B. Ö. (Ed.). (1906). Bir şehrin hıfzısıhhatı. Nevsal-i Afiyet, 4, 238-243. Ahmet İhsan ve Şürekası.

Akalın, B. Ö. (1904). İnşa ve hıfzıshhat-1 mesakin. Nevsal-i Afiyet, 3, 512-542. Ahmet İhsan ve Şürekası.

Çelik, Z. (1993). The Remaking of Istanbul: Portrait of an Ottoman City in the Nineteenth Century. University of California Press.

Demirhan, A. \& Kahya, E. (1997). Medicine in the Ottoman Empire (and Other Scientific Developments). Nobel Medical Publications.

Dinç, G. (1989). Arap Harfleri ile Türkçe Basılmış Tıbbi Süreli Yayınlar Toplu Kataloğu. Unpublished master's thesis, İstanbul Üniversitesi Sağlık Bilimleri Enstitüsü.

Ergin, O.N. (1995). Mecelle-i Umur-u Belediye (Vol. 6). İstanbul Büyükşehir Belediyesi Kültür İşleri Daire Başkanlığı.

Ergut, F. (2002). Policing the poor in the late Ottoman Empire. Middle Eastern Studies, 38(2), 149-164.

Foucault, M. (2000). The birth of social medicine. In J. D. Faubion (Ed.) Power (pp. 134-156). In P. Rabinow (Ed.) Power, Essential Works of Foucault 1954-1984, 3. New Press. 
Public Hygiene and Social Control in Late Ottoman İstanbul

Foucault, M. (1973). The Birth of the Clinic: An Archeology of Medical Perception. Tavistock Publications.

İnalc1k, H. (1994). The Ottoman Empire: The Classical Age 1300-1600. Phoenix.

Kahya, E. (1997). Ondokuzuncu Yüzyllda Osmanlı Imparatorluğu'nda Tip Eğitimi ve Türk Hekimleri. AYK Atatürk Kültür Merkezi Başkanlığı.

Kalkan, İ. (2015). Torture, Law and Politics in the Late Ottoman Empire (18401918). Unpublished doctoral thesis, New York University.

Karatay, S. (1971). 500 y1l sonra tıbbiyenin ve tıbbiyelinin toplumumuzdaki yeri. Türk İstanbul'da Tip Öğretiminin 500. Yıldönümü, 7-11. İstanbul Tıp Fakültesi.

Kırl1, C. (2001). The Struggle over Space: Coffeehouses of Ottoman İstanbul, 1780-1845. Unpublished doctoral thesis, Binghamton University.

Kranzler, K. L. (1991). Health Services in the Late Ottoman Empire. Unpublished master's thesis, Boğaziçi University.

Özbek, N. (2002). Osmanlı Imparatorluğu'nda Sosyal Devlet: Siyaset, İktidar, Meşruiyet. İletişim.

Özen, C. (1981). Türkiye'de adli tıbbın tarihçesi ve gelişmesi. Tıp Fakültesi Mecmuası, 44, 361-378.

Porter, D. (1999). Health, Civilization and the State: A History of Public Health from Ancient to Modern Times. Routledge.

Rosen, G. (1993). A History of Public Health. JHU Press.

Shaw, S. \& Shaw, E.K. (2002). History of the Ottoman Empire and Modern Turkey: Reform, Revolution and Republic: the Rise of Modern Turkey, 1808- 1975. Cambridge University Press.

Shefer-Mossensohn, M. (2009). Ottoman Medicine: Healing and Medical Institutions, 1500-1700. SUNY Press.

Şehsuvaroğlu, B.N. (1953). İstanbul'da 500 Yıllık Sağllk Hayatımız. İstanbul Fetih Derneği.

Unat, E.K. \& Samastı, M. (1992). Mekteb-i Tıbbiye-i Mülkiye. I. Türk Tip Tarihi Kongresi, İstanbul, 17-19 Şubat 1988, 113-125. Atatürk Kültür Dil ve Tarih Yüksek Kurumu yayınları. 
Yıldırım, N. (1985). Tanzimat'tan Cumhuriyet'e koruyucu sağlı uygulamaları. In Tanzimat'tan Cumhuriyet'e Türkiye ansiklopedisi (Vol. 5, pp. 13201338). İletişim.

Y1lmaz, C. \& Yılmaz, N (2006). Osmanlı hastahane yönetmelikleri: vakfiyelerde Osmanlı darüşşifaları. In C. Yılmaz \& N. Yılmaz (Eds.), Osmanlılarda Sağllk (Vol. 1, pp. 41-64). Biofarma.

Zorlu, T. (2002). Süleymaniye Tıp Medresesi-II. Osmanlı Bilimi Araştırmaları $4(1), 65-98$.

\section{EXTENDED ABSTRACT}

From the mid-nineteenth century in Ottoman Empire, one witnesses a categorical change with regard to how the state engaged with the question of health. In stark contrast with the traditional official Ottoman practice whereby the state had involved in the matters of health primarily for charity purposes, now the state started taking on the health of the population as a direct responsibility. This transformation marked the emergence of public health in Ottoman Empire, a consistent and systematic policy evolving over the course of the nineteenth century and beyond. This article comprehensively demonstrates the emergence and evolution of the Ottoman public health policy by tracing the birth and development of radically new institutions and official practices it involved. It furthermore asks why the official Ottoman approach to the health of population transformed and why specifically in the mid-nineteenth century.

Being Inspired particularly by the social and political theory developed by Michel Foucault, and by blending it fruitfully with the beginnings of the Ottoman public health, I suggest that the emergence of public health in Ottoman Empire was deeply indebted to an epistemological shift in medicine, more particularly, a drastic change in the meanings of both the body and the disease. Namely, both shifted from being conceived as individual, particular and unique to rather abstract, social and anonymous. This conceptual shift helped to imagine the whole population as one single body, hence to be controlled, shaped and ameliorated. During the same years when this epistemological shift in medicine occurred, also the notion of political power immensely transformed in Ottoman Empire.

The same kind of abstraction that led the change in the understanding of medicine also effected the emergence of a novel conception on the nature of political 
power. Similar to the body involving universal biological features and to be treated according to scientific norms, the individual became increasingly defined as being a uniform legal and political entity whose conduct should be managed in accordance with objective norms and principles. Hence the exercise of state authority became increasingly marked by the social control, something which became manifested in a wide range of policies which commonly carried the purpose to police the society. This article argues that it is foremost the entwinement between the development of this new form of power and transformation in medical epistemology that produced the public health in Ottoman Empire. This entwinement can be traced best in the official efforts from the mid-nineteenth century to reform the urban environment in Istanbul, where security and health concerns overlapped squarely.

Tracing through the archival records the evolution of the late Ottoman public health policy, I have explored that the official efforts to monitor and shape İstanbul's urban environment for the sake of public health dramatically intensified from the 1890s. These records include government issued pamphlets, health inspection reports and one significant annual of public health. In addition to bringing to light the regulations envisaged by the government, they also demonstrate what was done on the ground in accordance with these regulations and finally the mindset of the ruling elite with regard to public hygiene. By relying principally on these sources, the larger part of the article demonstrates how and discusses why this break occurred at the time it did.

The 1890s witnessed the government's launching of a wholesale public health campaign throughout the city, which involved the opening of completely novel institutions and unique practices. In addition to much more deeply monitoring the city, the campaign also brought about a meticulous intervention into the daily lives of its inhabitants to unprecedented extents. The new form of intervention targeted private alongside public spaces with the main purpose to ameliorate their physical conditions and prevent overcrowding inside. Arguably the most significant qualitative change that the new public health campaign brought to the evolution of the Ottoman public health policy was the emergence of a radically new concept, the urban poor. The ruling elite explicitly defined the poor as a distinct social category and characterized them as the main cause of the emergence and spread of diseases, something which can be traced also in the regulations and day-to-day hygiene inspections.

Why was it the 1890s when an extensive and qualitative break occurred in Ottoman public health policy? This article suggests that the reason lies in a set of overlapping developments, the most visible of which is the rise of cholera 
epidemics during these years. While cholera had erupted several times in İstanbul over the course of the nineteenth century, it attracted a uniquely extensive response from public authorities during the 1890 s, significantly due to its now being coupled with the birth of bacteriology which brought about a new understanding of how diseases spread. With bacteriology, it appeared urgent for the sake of public health to imagine the city as one single whole, with all the parts being connected to each other. Furthermore, İstanbul had been witnessing over decades steady population increase as a result primarily of extensive and ongoing immigration which particularly created overcrowding and poverty to now intolerable proportions. One should finally count on the development of the bureaucratic mechanisms of social control in Ottoman Empire over the course of the nineteenth century. 